\title{
Convergence and parallelism in evolution of structures and functions of ferns and other groups of plants
}

\author{
N. M. Derzhavina \\ Federal State Budgetary Educational Institution of Higher Education "Orel State University named after I. S. Turgenev" \\ Komsomolskaya,95, Orel, 302026,Russia.E-mail:d-nm@mail.ru
}

Key words: adaptatiogenesis, anatomical structures, functional peculiarities, morphological structures.

Summary. On the basis of own investigations and literature data, the similarity of structures and functions of ferns and unrelated and related species is demonstrated in connection with their adaptation to similar mode of life at the different levels of the organization of plants. Convergence is manifested at the level of organism and organ (similarity of morphological structures: entire fronds and simple leaves; long rhizomes; squamose rhizomes of ferns and imbricate bulbs of flowering plants; tuft biomorphs of ferns and flowering plants; shelters for ants and cups accumulating humus; absorbing scales; "complex" polyfunctional buds of rosette ferns with buds of flowering plants; gemmae of mosses and gametophytes of ferns). Convergence at the level of tissue and cells - is in similarity of anatomical structures: spiral thickening of cell walls in root cortical cells in epiphytic Polypodiaceae and velamen in Orchidaceae; multilayered water-storage parenchyma in fronds, rhizomes, tubers of ferns and an analogue tissue in flowering plants; palmate cells of epidermis and mesophyll in sciophytic ferns and sciophytic flowering plants; pyriform epidermal cells in ferns, selaginellas, and sciophytic mosses; protective shielding structures in fern epidermis). Convergence at the functional level - is in indirect parasitism at the cost of fungal symbiont in some epiphytic Polypodiaceae and in Orchidaceae; CAM photosynthesis in some epiphytic and lithophytic ferns, gymnosperms and angiosperms; mycotrophy (mutualistic co-parasitism); poikilohydry.

\section{Конвергенция и параллелизм в эволюции структур и функций папоротников и других групп растений}

\author{
Н. М. Державина
}

Орловский государственный университет им. И. С. Тургенева, ул. Комсомольская, 95, Орел, 302026, Россия

Ключевые слова: адаптациогенез, анатомические структуры, морфологические структуры, функциональные особенности.

Аннотация. На основе собственных исследований и литературных данных выявлено сходство структур и функций папоротников с неродственными и родственными видами на разных уровнях организации растений в связи с их приспособлением к сходному образу жизни. Конвергенция проявилась на организменном и органном уровнях (сходство морфологических структур: цельных вай и листьев, длинных ризомов, чешуйчатых ризомов папоротников и имбрикатных луковиц цветковых растений, дерновинных биоморф, вместилищ для муравьев и для накопления гумуса, абсорбирующих чешуй, «сложных» полифункциональных почек розеточных папоротников с почками цветковых растений, выводковых почек мхов и гаметофитов папоротников). Конвергенция на тканевом и клеточном уровнях - это сходство анатомических структур: спиральных утолщений клеток коры корней эпифитных Polypodiaceae и веламена Orchidaceae, многослойной водозапасающей паренхимы в вайях, ризомах, клубнях папоротников и аналогичной ткани у цветковых, дланевидных клеток 
эпидермы и мезофилла у папоротников-сциофитов и у цветковых-сциофитов, грушевидных клеток эпидермы у папоротников, селагинелл и у мхов-сциофитов, защитных экранирующих структур в эпидерме). Конвергенция на функциональном уровне - это сходство непрямого паразитизма за счет грибного симбионта некоторых эпифитных Polypodiaceae и Orchidaceae, CAM-типа фотосинтеза некоторых эпифитных и литофитных папоротников, голосеменных и цветковых, микотрофии (мутуалистического взаимного паразитизма), пойкилогидричности.

In the course of adaptatiogenesis, ferns developed secondary, i.e. not inherited from common ancestors, similarity of structures and functions with unrelated and related species in connection with their adaptation to similar mode of life. Conventionally, this similarity is associated with the phenomena of convergence and parallelism.

On the basis of own investigations (Derzhavina, 2008, 2010, 2012, 2013, 2015a, b) and literature data, we have made an attempt to reveal convergence and parallelism in the evolution of structures and functions of ferns and other plant groups.

\section{Results}

Convergences, as well as structural and functional analogies, are manifested both at the level of organism and organ (epimorphological), and at the level of tissue and cell:

A. Morphological structures - formal resemblance between:

1. Entire fronds (species of the genera Pyrrosia, Lemmaphyllum, Lepisorus, etc.) and simple leaves of flowering plants.

2. Long rhizomes of ferns covered by scales (Microgramma lycopodioides, Drynaria volkensii, Polypodium aureum, etc.) and the axes of Lycopodiophyta covered by photosynthetic microphylls having the enation origin Although the scales on fern rhizomes cannot photosynthesize, however, apart from their protective role, they can participate in translocation of water to the cortex of rhizomes in several Indian Pyrrosia species (Nayar, 1961).

3. Tuft biomorphs of ferns (species of Woodsia, Asplenium, Aleuritopteris) and flowering plants (the term "tuft" as applied to ferns is conditional enough; it was proposed by A.P. Khokhryakov (1979) on the principle of formal resemblance of dense arrangement of fronds and dense arrangement of shoots of flowering plants).

In these ferns, effect of extreme environment is compensated in some measure by the processes of polymerization of structures, manifested, primarily, in the formation of the tuft (cespitose) life form. Besides increase of number of terminal buds, abundant branching of rhizomes and dense arrangement of fronds, these ferns are characterized by the persistant stipes of thear dead fronds.

These compact structures, besides their main functions, have additional functions as well, which are important in extremal environmental conditions: they protect buds from parching effect of cold wind, high temperatures, excess insolation and transpiration. Dense "brush" of petioles retains fallen fronds, fine soil particles, etc., preventing their blowing-out by wind. Accumulating humus may promote geophytization - embedding of ferns into the substrate with formation of epigeogenic rhizomes. In the opinion of M. T. Mazurenko (1986), "Arctic and Arcto-Alpine ferns represent geophytized tuft plants" hiding either in rock clefts, or below the layer of broken stones.

4. Shelters for ants (in the case of myrmecophily) in epiphytic ferns of the genera Solenopteris and Lecanopteris (Davidson, Epstein,1989; Johns, 1995) and epiphytic flowering plants Myrmecodia, Hydnophytum, Myrmedoma, Myrmephytum and Squamellaria (Rubiaceae), Dischidia (Asclepiadaceae), Tillandsia (Bromeliaceae) (Huxley, 1980).

These plants have mutualistic relations with ants, which colonize the spaces in rhizomes (Lecanopteris, Solenopteris) and air tubers (Hydnophytum, Myrmecodia - Rubiaceae), internodes (Myrmeconauclea, Clerodendrum myrmecophylum - Verbenaceae), sacciform blisters on leaves - formicaria (Melastomataceae), etc.

Huxley (1980) noted some convergent similarity of structures inhabited by ants:

1. Presence of water-absorbing structures in them, however, having different origin and morphology. They include additional roots of Dischidia and Solenopteris; "blotches" (small white convex structures in spaces of tubers) in Myrmecodia, Hydnophytum, etc.; absorbing trichomes in Tillandsia; in Lecanopteris, the whole interior surface of the rhizome may absorb water. However, their functions in myrmecophytes from different biotopes are not elucidated completely.

2. Many myrmecophytes have dark-colored interior surface of the cavities. These cavities are 
colonized by ants; possibly, ants need dark places for nesting (Janzen, 1974; ref. in: Huxley, 1980).

3. All ant nests in plants have narrow tunnel-like entrances that open in a horizontal plane. They are arranged like inkpot, what prevents falling out of contents and accumulation of rainwater, as well as decrease amount of incoming light.

It turns out that cohabitation of plants with ants ecologically lifts the restriction on distribution of epiphytes in the conditions of deficit of nutrients and allows them colonizing hostile environments.

Therefore, ants and epiphytes have developed in most cases mutualism on the basis of commensalism. Interspecific interactions of plants and ants may be estimated as topical (they create the environment one another); trophic; fabric (ants use plant material for building of nests); rarely - phorical (in case of myrmecochory).

5. Cups accumulating humus in nest and niche ferns of the genera Asplenium, Drynaria, Platycerium, etc., and flowering plants of the families Araceae, Orchidaceae, Asclepiadaceae, etc.

In nest epiphytes, leaves (fronds) form a kind of funnel, where humus is accumulated and water is retained (Araceae, Orchidaceae, ferns - Asplenium nidus, Drynaria meyeniana). This substrate is transpierced by abundant intertmingled roots, resembling a bird's nest and supplying the plants with water and nutrients. Bracket epiphytes (Conchophyllum - Asclepiadaceae, ferns Drynaria laurentii, species of the genus Platycerium, etc.) accumulate humus and retain water in the spaces between leaves or fronds (having the shape of brackets) and tree bark.

6. Squamose rhizomes of ferns, whose axes are covered by long persisting, imbricate thickened frond bases (phyllo- or trophopodia) with a storage function (Athyrium filix-femina, Polystichum braunii, Dryopteris filix mas, etc.) and imbricate bulbs of flowering plants (Shorina, 2000).

7. Absorbing scales on fronds of some ferns of the family Polypodiaceae (Polypodium hirsutissimum, P. squalidum, P. polypodioides, Pleopeltis angusta) (Ogura, 1972) and on leaves of flowering plants (Bromeliaceae). L. Müller, G. Starnecker, S. Winkler (1981) proved that these trichomes were the analogues of water-absorbing scales of Bromeliaceae and likewise consist of living cells of stalk and dead cells of central disk, ring and wing. These scales absorb water through lignified cells of central disk, ring and wing and transport it inside the frond through the stalk cells.

8. "Complex" polyfunctional buds of rosette ferns such as those in flowering plants. Comple- xity of buds in such ferns is ensured by presence of multiple fronds at different phases of morphogenesis near the apex.

Chamaephytic ferns - Matteuccia struthiopteris, Osmunda asiatica periodically develop abortive fronds (cataphylls), which closely surround the terminal bud, ensuring its protection along with scales on unexpanded fronds. Such buds are called "closed buds" (Shorina, 2000). Although buds of other rosette ferns, for example, such as Athyrium filix-femina, have no specialized cataphylls and can be formally considered open buds, nevertheless, they have additional protection in the form of trophopodia of assimilating fronds covered by large filmy scales, as well as petioles of dead fronds. Moreover, such buds perform not only the function of regular reproduction, but, in the case of frond damage, they can form a new portion of fronds, becoming the analogues of proleptic and dormant buds of flowering plants. At the same time, in comfortable conditions, vigorous sporophytes can give rise to two generations of fronds, and in that case, the terminal bud becomes an analogue of the enrichment bud (Shorina, 2000).

9. Gemmae of mosses and gametophytes of ferns of the families Hymenophyllaceae, Vittariaceae (Surova, 1978). Here, formal resemblance is often based on different morphological structures.

B. Anatomical structures - formal resemblance between:

1. Spiral thickening of cell walls in root cortical cells in epiphytic Polypodiaceae (Schneider, 1996), Asplenium (et al., 2011) and velamen in Orchidaceae;

2. Multilayered water-storage (specialized and non-specialized) parenchyma in fronds (Derzhavina, 2008), rhizomes, tubers of ferns and an analogue tissue in flowering plants.

In most ferns (Lemmaphyllum microphyllum, Microsorium punctatum, Pyrrosia longifolia, etc.), as well as in cryptic succulents-angiosperms (Zygophyllum, Nitraria) (Gamaley, Shiyrevdamba, 1988), succulentization proceeds on the basis of polyfunctionality of chlorenchyma; and water storage may be a function of either hypodermis only, or palisade parenchyma, or spongy parenchyma, or the mesophyll as a whole. Judging by literature data, species of the genera Pyrrosia (Nayar, 1961; Hovenkamp, 1986) and Platycerium (Boyer, 1964; Froebe, Strank, 1981), inhabiting seasonal tropical climate, already have a specialized water-storage parenchyma.

However, among ferns, there are no highly specialized leaf succulents like Crassulaceae, 
Aizoaceae with fleshy cylindrical, etc., leaves, massive specialized water-storage parenchyma, high water-retaining power, and many other characteristics. In general, ferns are, in our opinion, "leaf" subsucculents or cryptic succulents. V. R. Filin (1995) used the term "semisucculents" for the fronds of Ophioglossum vulgatum with high water content. In contrast to typical leaf succulents, they retain water poorly, but absorb it quickly;

3. Palmate cells of epidermis and mesophyll in sciophyte ferns and sciophyte flowering plants (Lotova, Timonin, 1989); pyriform epidermal cells in ferns, selaginellas, and sciophyte mosses (Razdorsky, 1949; Singh, 1963);

4. Protective shielding structures in fern epidermis (crystals of calcium salts, as in Aizoaceae) (Ogura, 1972) and various trichomes and glands (trichomes at the lower surface in the genera Ceterach, Pyrrosia, Platycerium; glands in species of the genera Aleuritopteris, Cheilanthes, etc.) like that in flowering plants.

Jan Grzybek (1973) observed crystals of calcium oxalate on frond surface in Polypodium vulgare. In Aizoaceae, calcium crystals in epidermis act as a kind of matte glass, decreasing intensity of insolation reaching chlorophyll-bearing cells (Udalova, 1980). It is possible to suppose that they can have such a protective function in ferns as well.

Lower frond side in species of Pyrrosia, Platycerium is covered by dense blanket of dead stellate trichomes, in Ceterach officinarum - by brown clathrate scales with imbricate arrangement. In Aleuritopteris argentea, upper side of frond blades has spring green color, lower side is silverywhite due to secretory bicellular trichomes excreting waxy substance (Nayar, 1962, 1963; Derzhavina, 2006), which forms powder-like deposition. This adaptation allows fronds restraining excessive transpiration and, possibly, possesses shielding protective properties in conditions of high insolation.

\section{Functional peculiarities}

1. Indirect parasitism at the cost of fungal symbiont in some epiphytic Polypodiaceae (Pyrrosia piloselloides and P. nummulariifolia) and in Orchidaceae (Ruinen, 1953). Hazard of epiphytic invasion consists not only in coating of stems and branches of phorophytes by roots, rhizomes and rhizoids of epiphytes, but also in infection by mycorrhizal fungi, which turn to parasites in the new host. According to J. Ruinen, infection of phorophytes by symbiotic fungi (epiphytic invasion) takes place in the rhizosphere, and the larger the surface of stem and branches covered by roots, the higher is the possibility of infection by symbiotic fungi. Infection leads usually to moderate and increasingly serious tracheomycosis (damaging of tracheas by fungal hyphae), accompanied by tylosis and blocking of vessels by gum

2. CAM photosynthesis in some epiphytic and lithophytic ferns, gymnosperms (Schulze et al., 1976) and angiosperms.

After discovery of CAM metabolism in species of the family Polypodiaceae - Pyrrosia adnascens, P. confluens, P. dielsii, P. longifolia, Drymoglossum piloselloides (two latter species have CAM invariably, irrespective of ecological conditions), Dictimia brownii (Wong, Hew, 1976; Winter et al., 1983; Ong et al., 1986), Microsorium punctatum, Polypodium crassifolium and lithophyte Platycerium veitchii (Holtum, Winter, 1999), and Vittariaceae (Martin et al., 2005, etc.) and investigation of different aspects of ecological physiology of other ferns ( Griffiths, 1989; Kluge et al., 1989, etc.), a hypothesis about the origin of some ferns with different types of metabolism was proposed.

M. Kluge et al. (1989) noted that CAM does not allow epiphyte succulent ferns to withstand long drought periods, but that it is useful in improvement of carbon and water balance within short periods of water deficit. It is quite consistent with habitat conditions of these ferns in humid tropical forests, where the sun shines usually before midday, and it rains in the afternoons for a few hours, i.e., an alternation of wet and dry conditions takes place ("pulse type of water supply") with circadian rhythmicity.

3. Mycotrophy (mutualistic co-parasitism) in ferns of the families of Polypodiaceae, Hypolepidaceae, etc., and in angiosperms of the families of Ericaceae, Orchidaceae, etc., as well as in clubmosses. Of 426 spore plants studied, $43 \%$ were obligate mycotrophs, and only $9 \%$ - facultative mycotrophs (Wang, Qiu, 2006).

It is known that all Ophioglossaceae are obligate mycotrophs (Filin, 1978b), though they depend on mycorhhiza in different ways. Gametophytes of Hymenophyllaceae are facultative mycotrophs in natural conditions (Surova, 1978), gametophytes of clubmosses - obligate mycotrophs (Filin, 1978a).

Furman (1959; ref. in: Johansson, 1974), who took up a problem of mycotrophy, found, on the one hand, the contacts between roots of Orchidaceae, Bromeliaceae, Pteridophyta and mycelium, on the other hand, - only free-standing mycelium.

I. V. Kruger, I. L. Poponina (1979) studied mycosymbiotic structures in 35 fern species. They 
found no non-mycorrhyzal ferns. According to the degree of mycotrophy, ferns were divided into several groups: the level of mycorrhizal infection more than $30 \%, 20-30 \%$, less than $20 \%$. They found that the sporophytes of Polypodium vulgare (Polypodiaceae), Pteridium aquilinum (L.) Kuhn. (Hypolepidaceae), Gymnocarpium dryopteris (L.) Newm. (Athyriaceae), Phegopteris connectilis (Michx.) Watt (Thelipteridaceae) had vesicular arbuscular endotrophic mycorrhiza with Endogonium fungi. No mycorrhiza was found in gametophytes of these species. Infection of roots, in opinion of these authors, comes from the soil due to chlamydospores and sporocarps of Endogonium fungi that hibernate in the soil.

M. Kessler et al. (2010), who studied 126 species of ferns and clubmosses from Malaysia and Sulawesi, found mycorrhiza in 109 species for the first time. Here, most species had arbuscular mycorrhiza.

Orchidaceae, known to be obligate mycotrophs at early stages of their development; however, it is little known, to what extent mycorrhiza are important in the nutrition of mature plants, and the available data are controversial (Benzing, 1987).

4. Poikilohydry of ferns of the family Polypodiaceae (Pyrrosia, Platycerium, Polypodium polypodioides, etc.), Hymenophyllaceae, Cheilanthaceae, Aspleniaceae (Ceterach officinarum), Schizaeceae (Anemia rotundifolia, A. tomentosa), etc., and angiosperms of the genera Ramondia, Haberlea (Gesneriaceae), Myrothamnus (Myrothamnaceae), Chamaegigos (Scrophulariaceae), etc., clubmosses (Selaginella trisulcata), mosses and other organisms (Stuart, 1968; Kessler, Siorak, 2007).

This complex phenomenon - capability to withstand extremal and long-lasting dehydration and life in condition of water deficit - anhydrobiosis (Oppenheimer, Halevy, 1962) was poorly known in ferns and represented in few publications.

E. Rouschal (1938) damaging that dangerous changes in the palisade parenchyma cell volume in Ceterach officinarum were prevented due to two mechanisms: longitudinal collenchyma-like thickenings of some cell walls and gelification of dehydrated vacuoles, rich in catechin-like tannins. He noted the facts of extremal resistance of C. officinarum to water loss. In the experiments, fronds lost water more than $98 \%$ of total saturation without apparent injury. Experiments of H. Oppenheimer and A. Halevy (1962) confirmed these data. In the cells of palisade parenchyma, longitudinal cell wall thickenings were detected: thin regions alternated with thick ones. Similar structure was found in anticlinal cell walls in upper epidermis. In the opinion of the authors, thin regions of the wall act as cores that facilitate contraction of walls in case of xerotropic movements. Similar structure was observed in cell walls of the moss Mnium sp. studied by C. Steinbrinck (1903) (ref. in: Oppenheimer, Halevy, 1962).

O. Hambler (1961) (ref. in: Oppenheimer, Halevy, 1962), who studied Trilepis pilosa from West Africa, distinguished two types of plants depending on behavior of their chloroplasts in the conditions of desiccation: homoiochlorophytes chloroplasts (agglutinated) are retained and do not change their color in the conditions of anhydrobiosis; poikilochlorophytes - like Trilepis pilosa, they loss chlorophyll and form it anew after restoring life activity.

M. Kessler and Y. Siorak (2007) conducted experiments with 43 ferns, studying their relation to desiccation and subsequent rehydration. However, the experiments were conducted not with whole plants, but with cut fronds. They found that it was impossible to distinguish only poikilohydric and homoiohydric ferns in respect of ability to maintain water regimen. The authors distinguished six groups of ferns, which use different strategies for withstanding drought: poikilohydric, mesomorphic, xeromorphic, succulent, deciduous, retaining water in funnels.

Surprisingly, but 17 species of ferns are currently known from the Sahara. Among them Actiniopteris radiata, Cheilanthes coriacea, Ophioglossum polyphyllum, are growing in isolated populations at elevations above $1600 \mathrm{~m}$. Authors consider, that ferns are more frequent than initially thought in arid environments. In this case "biogeographical isolation is certainly a central factor explaining fern distribution inarid environments, as well as altitude, the presence of local abiotic refuges and physiological adaptations to drought" (Anthelme at al., 2011, p. 522).

Selection may be directed not only to perfection of main adaptive role of the structure, what is encountered in most cases, but also to replacement of it by a new role. In this connection, in regard to ferns, probably, it is possible to speak about one more way of acquisition of secondary resemblance paraconvergence, as similarity of homological and non-homological organs and structures, with their different adaptive role (Iordansky, 1994).

For example, development of hydathodes in ferns, though with more primitive structure than 
in most angiosperms, intended for excretion of excess water from fronds, may be considered as an example of convergence. Whereas, emergence of a new adaptive role in hydathodes of epiphyte ferns intake of water - as an example of paraconvergence. Hydathodes in Platycerium stemaria and $P$. angolense combine two functions: guttation and participation in intake of water (Boyer, 1964).

Change of storage function of rhizomes to the function of intake of nutrients and water in case of transition of ferns to myrmecophily makes these structures to be paracorvergent to storage structures of flowering plants - rhizomes, tubers, bulbs, etc.

There are numerous examples of parallelism. For instance, development of similar tufted biomorphs in ferns within the families Aspleniaceae, Woodsiaceae, which occupy similar ecological niches; presence of similar structural types of fronds in the genera and species of a single family, inhabitants of similar biotopes: hydromorphic - Ceratopteris cornuta and $C$. thalictroides; hygromorphic - Adiantum capillus-veneris, Crepidomanes latealatum, etc.; mesomorphic - species of the genera Asplenium, Microgramma, Polypodium, Phyllitis, Platycerium, etc.; subxeromorphic - in species of the genera Pyrrosia, Ceterach, Lepisorus, Aleuritopteris, etc.; subsucculent - Antrophyum (Vittariaceae) (Gladkova, 1978), Pyrrosia, Platycerium, Lemmaphyllum, Microsorium (Polypodiaceae) (Derzhavina, 2008); CAM photosynthesis in species of a single genus Pyrrosia, etc.

Enhancement of ecological expansion in this group of organisms took part, probably, due to epectomorphoses (Iordansky, 1990) - development of such wide-spectrum adaptations, which affect dispersal (expansion of ranges) and broadening of ecological amplitude of ferns markedly. At that, their structural and functional level does not change, i. e., epectomorphoses does not lead to morphophysiological progress or regress, but allow ferns to expand old or occupy new ecological niches.

\section{Conclusion}

The carried out research convinces that in the morphofunctional systems of fern the most mobile adaptive structures are, first of all, fronds. Individual structural components (mesophyll, cells, etc.) of this heterogeneous adaptive complex are connected by complex communications among themselves and with other elements of various systems of an organism (rhizomes, roots).

The functional variability of fern sporophytes is manifested primarily in the phenomenon of secondary poikilohydry, as a reaction to the seasonal climate with long dry seasons, and in succulentization as a reaction to the conditions of a humid tropical climate in which short-term dryness alternates with heavy showers, as well as mycotrophy - the conjugate evolution of ferns and fungi, whose adaptive value consists in effective adaptation of organisms to the environment in the conditions of the competition.

Apparently, competition with flowering plants for the same resources in similar habitats was for ferns the evolutionary factor that led to the diversification of their ecological niches, specialization of types, convergence, structural and functional analogies, the flash of biodiversity and increase the adaptive level of many taxa.

\section{REFERENCES}

Anthelme F., Abdoulkader A., and Viane R. 2011. Are ferns in arid environments underestimated? Contribution from the Saharan mountains. J. Arid Environments 75: 516-523.

Benzing D. H. 1987. Vascular epiphytism: taxonomic Participation and adaptive diversity. Ann. Miss. Bot. Gard. 74(2): 183-204.

Boyer Y. 1964. Contribution a la étude de l'ecophysiologie de deux fougéres épiphytiques: Platycerium stemaria et P. angolense. Ann. Sci. Nat. Ser. 12(5): 87-228 [In French].

Davidson D. W., Epstein W. W. 1989. Epiphytic Associations with Ants. In: Vascular Plants as Epiphytes. Ed. U. Luettge. Springer-Verlag, Berlin, Heidelberg, 200-229 pp.

Derzhavina N. M. 2006. Biomorfologiya i anatomiya ravnosporovykh paporotnikov (epilitov, epifitov, zemnovodnykh $i$ vodnykh) v svyazi s adaptaciogenezom [Biomorphology and anatomy of homosporous ferns (epilithophytes, epiphytes, amphibious and aquatic) in connection with adaptatiogenesis: Abstract of the thesis of the Dr.Sci.Biol. Moscow, 50 pp. [In Russian]. (Державина Н. М. Биоморфология и анатомия равноспоровых папоротников (эпилитов, эпифитов, земноводных и водных) в связи с адаптациогенезом: Автореф. дис. ... докт. биол. наук. M., 2006. 50 c.).

Derzhavina N. M. 2008. Types of mesophyll in fern fronds and variants of their structural variability. In: Perspectives in Pteridophytes. Eds S. C. Verma, S. P. Khullar, H. K. Cheema. Bishen Singh Mahendra Pal Singh, Dehradun, India, 227-241 pp. 
Derzhavina N. M. 2010. Ecological classification of vascular epiphytes. Indian Fern J. 27: 32-52.

Derzhavina N. M. 2012. Adaptation of ferns to epiphytic mode of life: a case of Platycerium willinckii and Asplenium nidus. Indian Fern J. 29: 164-182.

Derzhavina N. M. 2013. Evolutionary restrictions and compensatory adaptations in homosporous ferns. Indian Fern J. 30: 255-267.

Derzhavina N. M. 2015a. Adaptation of epilithic ferns on different levels of structural organization. Contemporary Problems of Ecology 8(2): 141-147.

Derzhavina N. M. 2015b. Adaptive Strategies of homosporous Helophytic and Hydrophytic ferns. Contemporary Problems of Ecology 8(5): 560-573.

Filin V. R. 1978a. Lycopodiaceae. In: Zhizn rasteniy [Plant life. Ed. by A. L. Takhtajan]. Prosveshcheniye, Moscow, 4: 104-112 [In Russian]. (Филин В. P. Семейство Lycopodiaceae // Жизнь растений / Под ред. А. Л. Тахтаджяна. М.: Просвещение, 1978а. Т. 4. С. 104-112).

Filin V. R. 1978b. Ophioglossaceae. In: Zhizn rasteniy [Plant life. Ed. by A. L. Takhtajan]. Prosveshcheniye, Moscow, 4: 171-175 [In Russian]. (Филин В. Р. Семейство Ophyoglossaceae // Жизнь растений / Под ред. А. Л. Тахтаджяна. М.: Просвещение, 1978b. Т. 4. С. 171-175).

Filin V. R. 1995. Serpent's-tongue (Ophioglossum vulgatum). In: Biologicheskaya flora Moskovskoy oblasti [Biological flora of the Moscow region. Eds. V. N. Pavlov, V. N. Tikhomirov]. MGU-Argus, Moscow, 11: 4-36 [In Russian]. (Филин В. P. Ужовник обыкновенный // Биол. флора Моск. обл. / Под ред. В. Н. Павлова и В. Н. Тихомирова. Вып. 11. М.: Изд-во МГУ; Изд-во «Аргус», 1995. С. 4-36).

Froebe H. A., Strank K. J. 1981. Zum Wasserhaushalt von Platycerium Desv. Beitr. Biol. Pflanzen 56: 275-291.

Gamaley Yu. V., Shiyrevdamba C. 1988. Structural types of desert plants. In: Pustyni Zaaltayskoy Gobi. Kharakteristika rasteniy-dominantov [Deserts Transaltai Gobi: Characteristics of dominant plants]. Nauka, Leningrad, 45-67 pp. [In Russian]. (Гамалей Ю. В., Шийрэвдамба Ц. Структурные типы пустынных растений // Пустыни Заалтайской Гоби. Характеристика растений-доминантов. Л.: Наука, 1988. С. 45-67).

Gladkova V. N. 1978. Vittarioideae. In: Zhizn rasteniy [Plant life. Ed. by A. L. Takhtajan]. Prosveshcheniye, Moscow, 4: 194-195 [In Russian]. (Гладкова B. H. Vittarioideae // Жизнь растений / Под ред. А. Л. Тахтаджяна. М.: Просвещение, 1978. Т. 4. С. 194-195).

Griffiths H. 1989. Carbon Dioxide Concentrating Mechanisms and the Evolution of CAM in Vascular Epiphytes. In: Vascular Plants as Epiphytes. Ed. U. Lüttge. Springer-Verlag, Berlin Heidelberg, 42-81 pp.

Grzybek J. 1973. Biological and phytochemical investigations on Polypodium vulgare L. I. Anatomical analysis. Acta Biol. Cracov. Ser. Bot. XVI(1): 29-35.

Holtum J. A. M., Winter K. 1999. Degrees of crassulacean acid metabolism in tropical epiphytic and lithophytic ferns. Australian Journal of Plant Physiology 26(8): 749.

Hovenkamp P. 1986. A monograph of the genus Pyrrosia (Polypodiaceae). E. J. Brill, Leiden University Press, (Leiden Botanical Series, vol. 9), 280 pp.

Huxley C. 1980. Symbiosis between ants and epiphytes. Biol. Rev. 55: 321-340.

Iordansky N. N. 1990. Evolyuciya kompleksnykh adaptaciy [Evolution of complex adaptations]. Nauka, Moscow, 310 pp. [In Russian]. (Иорданский Н. Н. Эволюция комплексных адаптаций. М.: Наука, 1990. 310 c).

Iordansky N. N. 1994. Makroevolyuciya: sistemnaya teoriya [Macroevolution: a system theory]. Nauka, Moscow, 112 pp. [In Russian]. (Иорданский Н. Н. Макроэволюция: системная теория. М.: Наука, 1994. 112 с.).

Johansson D. 1974. Ecology of vascular epiphytes in West African rain forest. Acta Phytogeogr. Suec. 59: 1-136.

Johns R. J. 1995. Lecanopteris lomarioides (Polypodiaceae). Bot. mag. Kew. 12: 89-95.

Kessler M. et al. 2010. A survey of the mycorrhization of Southeast Asian ferns and lycophytes. Plant Biology 12: 788-793.

Kessler M. \& Siorak Y. 2007. Desication and rehydration Experiments on Leaves of 43 Pteridophyte Species. Amer. Fern J. 97(4): 175-185.

Khokhryakov A. P. 1979. Life forms of pteridophytes, their origin and evolution. Izvestiya Akademii nauk SSSR. Seriya biologicheskaya [Proceedings of the Russian Academy of Sciences. Biology] 2: 251-264 [In Russian]. (Xoxряков А. П. Жизненные формы папоротникообразных, их происхождение и эволюция // Изв. АН СССР. Сер. биол., 1979. № 2. С. 251-264).

Kluge M., Avadhani P. N., Goh C. J. 1989. Gas Exchange and Water Relations in Epiphytic Tropical Fern. In: Vascular Plants as Epiphytes. Ed. U. Lüttge. Springer-Verlag, Berlin Heidelberg, 87-107 pp.

Kruger I. V., Poponina I. L. 1979. Mycosymbiotrophism of ferns and some problems of their biology. In: Mikoriza rasteniy: respublikanskiy sbornik nauchnykh trudov [Plant Mycorrhiza: the Republican collection of scientific works]. Perm, 19-25 pp. [In Russian]. (Крюгер И. В., Попонина И. Л. Микосимбиотрофизм папоротников и некоторые вопросы их биологии // Микориза растений: республик. сб. науч. тр. Пермь, 1979. С. 19-25).

Leroux O., Bagniewska-Zadworna A., Rambe S. K., Knox J. P., Marcus S. E., Bellefroid E., Stubbe D., Chabbert B., Habrant A., Claeys M., Viane R. L. L. 2010. Non-lignified helical cell wall thickenings in root cortical cells of Aspleniaceae (Polypodiales): histology and taxonomical significance. Ann. Bot. (Oxford) 107: 195-207. 
Lotova L. I., Timonin A. K. 1989. Sravnitelnaya anatomiya vysshikh rasteniy: uchebno-metodicheskoe posobiye [Comparative anatomy of higher plants: study guide]. Izdatelstvo MGU, Moscow, 80 pp. [In Russian]. (Лomoвa Л. И., Тимонин $\boldsymbol{A}$. К. Сравнительная анатомия высших растений: учебно-метод. пособие. М.: Изд-во Моск. ун-та, 1989. 80 с.).

Martin Sh. L., R. Davis, P. Protti, Teng-Chiu Lin, Shin-Hwe Lin, C. E. Martin. 2005. The occurrence of Crassulacean acid metabolism in epiphytic ferns, with an emphasis on the Vittariaceae. International J. of Plant Sciences 166(4): 623-630.

Mazurenko M. T. 1986. Biomorfologicheskiye adaptacii rasteniy Kraynego Severa [Biomorphological adaptations of Far North plants]. Nauka, Moscow, 209 pp. [In Russian]. (Мазуренко M. T. Биоморфологические адаптации растений Крайнего Севера. М.: Наука, 1986. 209 с.).

Müller L., Starnecker G., Winkler S. 1981. Zur Oekologie epiphytischer Farne in Südbrasilien I. Saugschüppen. Flora 171: 55-63.

Nayar B. K. 1961. Ferns of India. Studies in Polypodiaceae. VII. Pyrrosia Mirbel. J. Indian. Bot. Soc. 40: 144-186.

Ogura Y. 1972. Comparative anatomy of vegetative organs of the Pteridophytes. Borntraeger, Berlin-Stuttgart, $502 \mathrm{pp}$

Ong B. L., Kluge M., Friement V. 1986. Crassulacean acid metabolism in the epiphytic ferns Drymoglossum piloselloides and Pyrrosia longifolia: studies on the responses to environmental signals. Plant Cell. Enrivon. 9: 547557.

Oppenheimer H. R., Halevy A. H. 1962. Anabiosis of Ceterach officinarum Lam. et DC. Bull. Res. Counc. of Israel 3: 127-147.

Razdorsky V. F. 1949. Anatomiya rasteniy [Plant anatomy]. Sovetskaya nauka, Moscow, 524 pp. [In Russian]. (Раздорский В. Ф. Анатомия растений. М.: Советская наука, 1949. 524 с.).

Rouschal E. 1938. Eine Physiologische Studie an Ceterach officinarum. Flora 132: 305-318.

Ruinen J. 1953. Epiphytosis. A second view on epiphytism. Ann. Bogoriensis 1(2): 101-157.

Schneider H. 1996. The Root Anatomie of Ferns: a comparative Study. In: Pteridology in Perspective. Rojal Botanic Gardens, Kew, 271-283 pp.

Schulze E. D., Ziegler H., Stichler W. 1976. Environmental control of crassulacean acid metabolism in Welwitschia mirabilis Hook. Fil. in its range of natural distribution in the Namib desert. Oecologia 24(4): 323.

Shorina N. I. 2000. Morphology of buds and rhizomes of ferns. In: Rasteniya v prirode i kulture [Plants in Nature and Culture]. Dalnauka, Vladivostok, 2: 124-138 [In Russian]. (Шорина Н. И. Морфология почек и корневищ папоротников // Растения в природе и культуре. Владивосток: Дальнаука, 2000. Т. 2. С. 124-138).

Singh T. C. N. 1963. An anatomical and ecological study of some ferns from Mussoorie (North-Western Himalayas). J. Indian Bot. Soc. 42(4): 475-543.

Stuart Tim S. 1968. Revival of Respiration and Photosynthesis in Dried Leaves of Polypodium polypodioides. Planta (Berlin) 83: 185-206.

Surova T. D. 1978. Hymenophyllaceae. In: Zhizn rasteniy [Plant life. Ed. by A. L. Takhtajan]. Prosveshcheniye, Moscow, 4: 218-222 [In Russian]. (Сурова T. Д. Нуmenophyllaceae // Жизнь растений / Под ред. А. Л. Тахтаджяна. М.: Просвещение, 1978, Т. 4. С. 218-222.

Udalova R. A. 1980. Aizoaceae. In: Zhizn rasteniy [Plant life. Ed. by A. L. Takhtajan]. Prosveshcheniye, Moscow, 5: 350-353 [In Russian]. (Удалова P. A. Aizoaceae // Жизнь растений / Под ред. А. Л. Тахтаджяна. М.: Просвещение, 1980. Т. 5. С. 350-353).

Wang B., Qiu Y.-L. 2006. Phylogenetic distribution and evolution of mycorrhizas in land plants. Mycorrhiza 16: 299-363.

Winter K., Wallace B. J., Stocker G. C., Rocksandic Z. 1983. Crassulacean acid metabolism in australian vascular epiphytes and some related species. Oecologia 57, 1-2: 129-141. DOI: 10.1007/BF00379570.

Wong Y. S. \& Hew C. S. 1976. Diffusive resistance, titrable acidity, and $\mathrm{CO}_{2}$ fixation in two tropical epiphytic ferns. Amer. Fern. J. 66: 121-124. 